LEIĨ̃O, Débora Krische; LIMA, Diana Nogueira de Oliveira; PINHEIRO MACHADO, Rosana (Org.). Antropologia e consumo: diálogos entre Brasil e Argentina. Porto Alegre: Age, 2006. $211 \mathrm{p}$.

\author{
Maria Luisa Célia E. de Dios* \\ Universidade Federal do Rio Grande do Sul - Brasil
}

\title{
Consumo, logo existo
}

A obra Antropologia \& Consumo, organizada por três antropólogas que realizam trabalhos na área do consumo, é o resultado do simpósio Consumo e Construção de Sujeitos e Bens no Mundo Contemporâneo, realizado no Primeiro Congresso Latino-Americano de Antropologia, em Rosário, Argentina, em 2005. A seleção dos textos e os assuntos abordados apresentam o consumo sob vários aspectos, mostrando como o tema é abrangente e como ele permeia a vida dos sujeitos inseridos numa sociedade urbana contemporânea. Os trabalhos aqui reunidos nos mostram como a questão do consumo se entranha na cultura brasileira, na cidadania, na saúde, nos diferentes estratos sociais, e como mobiliza a formação, transformação e consolidação de identidades. As diferentes origens teórico-conceituais e experiências de campo dos 15 autores, brasileiros e argentinos, resultam em uma obra rica, de temáticas diversificadas e surpreendentes. Os artigos denotam amadurecimento teórico, densidade etnográfica, características as quais fazem com que o leitor conheça, através dos textos, como discussões acadêmicas de ponta sobre consumo e práticas investigadas se imbricam.

O livro está dividido em cinco capítulos. No Capítulo I, “Consumo e Cultura Brasileira”, traz dois artigos interessantes que abordam o assunto de maneira inusitada. Com o sugestivo título de O Luxo do Povo e o Povo do Luxo: Consumo e Valor em Diferentes Esferas Sociais no Brasil, as autoras Krische Leitão e Pinheiro Machado, tendo como origem duas etnografias aparentemente opostas, investigam qual o significado da pirataria de marcas ou grifes

* Mestranda em Antropologia Social. 
de luxo - símbolos de status e poder -, e em contrapartida a apropriação de itens da cultura popular por profissionais da moda, questionando a democratização das práticas de consumo num país que segundo as autoras se pensa híbrido, cordial e aberto à fluidez e à permeabilidade. No segundo artigo, Mais Feijoada e Samba: Notas sobre a Cultura Negra Brasileira, Rezende Gonçalves e Alves Ribeiro discorrem com ineditismo a questão, tão debatida e polêmica, entre a cultura negra e cultura brasileira, os limites tênues e inconstantes de ambas, problematizando o assunto através da feijoada e do samba trazendo a tona e pondo em xeque algumas certezas sobre como o local e o global se engendram mútua e continuamente através das suas historicidades.

Já, no Capítulo II, “Consumo e Cidadania na Argentina”, Ana Wortman nos brinda com uma excelente análise, trazendo à tona as complexas e invisíveis conexões sobre a nova conformação cultural que emerge na Argentina, denominada pela autora de esfera pública paralela, por meio de determinadas práticas e campos culturais - cinema, música e teatro, em seu artigo Sociedade Civil na Argentina Pós-Crise: a Conformação de uma Esfera Pública Paralela. De maneira diversa Pina e Arribas, atentas ao atual momento argentino, refletem sobre o significado e as perspectivas de uma categoria emergente: o cidadão consumidor. No texto O Cidadão Consumidor: o Nascimento de uma Nova Categoria, versam sobre a intersecção das categorias consumidor e cidadão, e como elas propiciarão um consumo mais cidadão, através da abertura de novos espaços reivindicatórios, conseqüência da implementação da lei do consumidor.

O tema "Consumo e Saúde”, Capítulo III, prima pela maneira singular com que é tratado pelos autores. O primeiro artigo aborda o assunto por meio de uma etnografia sobre o consumo de imagens fetais, numa clínica de ultrasonografia, descrita e analisada brilhantemente pela antropóloga Lílian Chazan. No segundo artigo o autor Rogério Lopez Azize instaura uma discussão sobre os medicamentos do bem-estar e da auto-estima, como são designados o Prozac, Viagra e Xenical, trabalhando com reportagens, discursos de usuários e dos médicos que conceberam a ingestão desses medicamentos com estilo de vida, ressemantizando a dualidade saúde-doença.

Dando continuidade ao tema, o Capítulo IV, “Consumo e Classe Social”, propõe-se a retratar o significado do consumo em esferas sócias opostas. O artigo de Sergio Castilho pondera como é o consumo em classes ditas populares, mostrando que, antes de ser excludente, o consumo, age como fator de inclusão e pertencimento dos indivíduos estudados na sociedade envolvente, 
definindo identidades e dando a conhecer a sua visão de mundo. O artigo aponta dados e conclusões interessantes, ainda que por vezes exagere no uso dados estatísticos. Ao ler o artigo de Patrícia Gomensoro somos arremessados para o outro lado da dimensão social. Etnografando um grupo de degustadores de vinho, Gomensoro, nos dá a conhecer até que ponto o exercício da degustação torna-se um sinal emblemático que separa os connaisseurs, com percepção esclarecida, das pessoas comuns: é Bourdieu na prática.

Completando a obra, o Capítulo V, “Consumo e Identidades Jovens”, como o próprio título faz referência, discute dimensões simbólicas das práticas dos jovens relacionadas com o consumo musical, em Buenos Aires, e o vestuário, na cidade do Rio de Janeiro. A antropóloga argentina Cecília Benedeti traz à baila uma detalhada discussão sobre como o rock contemporâneo argentino pode ser (re)pensado como bem de consumo cultural e como espaço de sociabilidade. Ela também trata da ressignificação de valores nesse campo, mostrando como alguns sinais delimitam uma identidade dita roqueira em certos grupos de jovens urbanos da cidade de Buenos Aires.

Abordando o tema dos estilos de vida, a autora Marcela Pias Andrade percorre centros culturais em determinados bairros da capital portenha, onde investiga e caracteriza as práticas de consumo cultural desenvolvidas por grupos de jovens de estratos sociais médios. Ela analisa como estas práticas delimitam contornos de gosto, hábitos e estilos de vida.

Cidade maravilhosa, morros cariocas, música funk e seus figurinos são as temáticas escolhidas por Mylene Mizrahi, ao etnografar um grupo de jovens participantes de bailes funk dos morros do Rio de Janeiro. A autora mostra como esses itens se imbricam para construir uma identidade jovem urbana por ela denominada de "identidade funqueira". A novidade introduzida pela autora no seu artigo reside em sublinhar a importância da análise das características materiais dos objetos, algumas vezes deixadas de lado quando empreendemos estudos sobre os significados simbólicos.

Eis a questão: por que ler o livro? Porque através de um trabalho teóricoprático muito bem fundamentado os autores resgatam, através de inusitadas e ao mesmo tempo, poderíamos dizer, até triviais práticas de consumo, a alteridade, a diversidade, a produção de significado demarcando a perspectiva cultural da construção dos grupos e dos indivíduos investigados, ligando-os ao aspecto relacional dessa construção. Enfim, é dessa maneira que a obra captura os modelos alternativos, as possibilidades de inclusão, negociação entre os sujeitos, ressemantização, cidadania que o consumo adquire atualmente na sociedade contemporânea. 